\title{
Adsorption and native microbiota of an agricultural soil are involved in the removal of fluoranthene
}

\author{
O. J. Hernández-Hernández ${ }^{1 \S}$, L. R. Evaristo-Vázquez ${ }^{1 \S}$, M. S. Vásquez-Murrieta ${ }^{1}$, C. M. \\ Flores-Ortiz ${ }^{2}$, A. Ponce-Mendoza ${ }^{3}$, H. Flores-Herrera ${ }^{4}$, J. C. Cancino-Díaz ${ }^{1}$, J. A. Cruz- \\ Maya $^{5}$, J. Jan-Roblero ${ }^{1 *}$
}

${ }^{1}$ Departamento de Microbiología, ENCB, Instituto Politécnico Nacional, Prol. de Carpio y Plan de Ayala s/n. Col. Sto. Tomás. Ciudad de México. 11340, México. ${ }^{2}$ Laboratorio de Biogeoquímica, UBIPRO, FES Iztacala, UNAM, Av. de los Barrios No. 1, Los Reyes Iztacala, Tlalnepantla, Estado de México 54090, México. ${ }^{3}$ Comisión Nacional para el Conocimiento y Uso de la Biodiversidad, CONABIO, Insurgentes Sur 4903, Col. Parques del Pedregal, Ciudad de México 14010. México. ${ }^{4}$ Departamento de Bioquímica y Biología Molecular, Instituto Nacional de Perinatología "Isidro Espinosa de los Reyes", Ciudad de México D. 11000, México. ${ }^{5}$ Unidad Profesional Interdisciplinaria en Ingeniería y Tecnologías Avanzadas, Instituto Politécnico Nacional, Av.IPN 2580,Ciudad de México.07340, México. *Correspondingauthor:jjan_r@yahoo.com.mx

$\S$ : Both authors contributed equally to this work.

\begin{abstract}
Several factors can influence the removal of polycyclic aromatic hydrocarbons from agricultural soils, such as the native microbiota, the physicochemical properties of the soil, soil management and addition of exogenous microorganisms. Nevertheless, the involvement of these factors has not been studied during fluoranthene removal at the microcosm level. In the present study, the effects of these factors were evaluated in microcosms composed of an organic agricultural soil (OAS-microcosm) and conventional agricultural soil (CAS-microcosm) contaminated with fluoranthene. According to their physicochemical properties, both soils were classified as silt loam. They had similar cation exchange capacities, water holding capacities and P-PO4 ${ }^{3-}$, but different pHs, electrical conductivities, and percentages of N, C, silt, clay and sand. Fluoranthene did not alter the native microbiota of the OAS- and CAS-microcosm because similar banding profiles were obtained in PCR-DGGE analysis of the 16S rRNA gene, and the total heterotrophic bacteria count as well as fluoranthene-degrading bacteria count were similar between microcosms with fluoranthene and their controls without fluoranthene. However, OAS- and CAS-microcosms showed higher respiratory activity than their controls $(p<0.05)$. At the beginning of the degradation kinetics, OAS- and CAS-microcosms reached a higher percentage of fluoranthene removal than their abiotic counterparts (adsorption controls; $p<0.05$ ); towards the end of the degradation kinetics, no significant difference was observed between the OAS- and CAS-microcosms and their corresponding adsorption controls. The bioaugmentation assay using a fluoranthene-degrading bacterial consortium increased fluoranthene removal. This work showed that fluoranthene adsorption to soil and native microbiota of agricultural soils were involved in fluoranthene removal.
\end{abstract}

Keywords: Fluoranthene, microcosm, agricultural soil, native microbiota, PCR-DGGE, 16S rRNA gene 


\section{Introduction}

Polycyclic aromatic hydrocarbons (PAHs) are organic molecules that pose a high risk to humans and to the environment. The US Environmental Protection Agency designated them as toxic, mutagenic, carcinogenic, and priority pollutants. PAHs are formed by two or more fused aromatic rings arranged in a linear, angular, or cluster array. They are classified as lowmolecular-weight (LMW) PAHs that are formed by two or three benzene rings and as high-molecularweight (HMW) PAHs that are formed by four or more benzene rings. Some physical processes are effective in reducing the environmental level of PAHs; however, biodegradation is usually the preferred and major route of PAH removal from contaminated environments because of its cost, effectiveness and complete clean-up. One alternative to the bioremediation of PAHs-contaminated soil is through bioaugmentation: the introduction of microorganisms that are capable of degrading a pollutant in contaminated soil (Azubuike et al., 2016).

Several studies on the isolation of bacteria that remove PAHs have been recently completed. LMWPAHs can be more easily degraded by bacteria, whereas HMW-PAHs, such as fluoranthene, are more recalcitrant to biodegradation and persist in the environment. The bacterial genera Burkholderia, Pasteurella, Rhodococcus, Stenotrophomonas, Sphingomonas and Mycobacterium are able to remove fluoranthene (Haritash and Kaushik, 2009; Simon et al., 2004; Sprocati et al., 2012; Viñas et al., 2005). However, their ability to degrade fluoranthene has been studied in a minimal culture medium supplemented with the PAHs as the sole carbon source (Jin et al., 2016). The extrapolation of bioaugmentation to the microcosm level or to field conditions has not always yielded expected results (Crisafi et al., 2016). Studies on bioaugmentation through microor- ganisms with a recognized ability to degrade PAHs in contaminated soil have generated non-conclusive data: in some cases, bioaugmentation has increased the degradation of PAHs (Sprocati et al., 2012), and in other cases, it has been ineffective (Simon et al., 2004; Viñas et al., 2005). The latter result occurred because some factors affecting the adaptation of the introduced microorganisms were not considered (Long et al., 2014), resulting in a low efficiency of PAHs degradation. The most common of these factors are: the response of the native microbiota to the introduced microorganisms; intrinsic physicochemical properties of the soil, mainly the organic carbon, silt, clay and sand contents; soil management; and addition of fertilizers and pesticides. Comprehensive studies on PAHs degradation are hindered by the complexity of the microbial-ecological diversity in soil. Previous studies have mainly focused on agricultural soils because pollution of these soils affects the production and quality of crops; PAHs contamination is specifically relevant because of their toxic effects. In this paper, some natural factors involved in fluoranthene removal (a compound used as a model of PAHs) in an agricultural soil were evaluated. Fluoranthene-contaminated soil microcosms were designed, and the soil physicochemical properties, participation of native soil microbiota, effect of bioaugmentation and impact of fertilizers and pesticides in soil were studied.

\section{Materials and Methods}

\subsection{Experimental site and soil sampling}

Soil samples were collected in the state of Puebla, located in the central part of the Mexican Republic $\left(18^{\circ} 29^{\prime} \mathrm{N}, 97^{\circ} 51^{\prime} \mathrm{W}\right.$ and $2,160 \mathrm{~m}$ of altitude). Organic 
agricultural soil (OAS, considered as the unimpacted soil) was obtained from a temporary agricultural land that was untreated with fertilizers and pesticides, was not polluted with heavy metals or hydrocarbons, had a zero tillage system, and had a crop rotation of corn and beans. By contrast, conventional agricultural soil (CAS, considered as the impacted soil) was obtained from soil treated with chemical fertilizers and pesticides, in which conventional agricultural practices were used. Soil samples were taken to a depth of $15-$ $20 \mathrm{~cm}$. The equivalent weight samples of OAS and CAS were mixed in a vessel to obtain a composite sample. The soil was transported in sealed bags and stored at $4^{\circ} \mathrm{C}$ for further processing.

\subsection{Physicochemical properties}

The soil $\mathrm{pH}$ was measured in a $1: 1$ soil: $\mathrm{H}_{2} \mathrm{O}$ suspension using a glass electrode. The humidity was evaluated by the gravimetric method. The water holding capacity (WHC) was measured as the amount of water retained by the soil against the force of gravity after the soil was saturated with water and drained freely. The soil particle size distribution was determined by the hydrometer method. The electrical conductivity was measured in a soil suspension as described by Rhoades et al. (1989). The soil cation exchange capacity was measured by extracting soil with a solution of barium chloride, followed by cation exchange of $\mathrm{Ba}^{2+}$ for $\mathrm{Mg}^{2+}$ performed on the extract. $\mathrm{Mg}^{2+}$ was then titrated with a solution of EDTA. The total carbon (C) in soil was determined by oxidation with $\mathrm{K}_{2} \mathrm{Cr}_{2} \mathrm{O}_{7}$ and titration of excess dichromate with $\left(\mathrm{NH}_{4}\right)_{2} \mathrm{FeSO}_{4}$. The inorganic $\mathrm{C}$ in soil was determined by adding $20 \mathrm{~mL}$ of a $1 \mathrm{M} \mathrm{HCl}$ solution to $2 \mathrm{~g}$ of air-dried soil and trapping the $\mathrm{CO}_{2}$ evolved in $20 \mathrm{~mL}$ of $1 \mathrm{M} \mathrm{NaOH}$. The $\mathrm{CO}_{2}$ in the $\mathrm{NaOH}$ solution was determined by titration with $0.1 \mathrm{M} \mathrm{HCl}$. Organic $\mathrm{C}$ was calculated as the difference between total and inorganic $\mathrm{C}$. Total $\mathrm{P}$ was measured by aqua regia digestion with sodium carbonate fusion. The available $\mathrm{P}$ in the $0.5 \mathrm{M} \mathrm{NaHCO}_{3}$ extract was determined by the antimony-potassiumtartrate method. Total $\mathrm{N}$ was measured by the Kjeldahl method using concentrated $\mathrm{H}_{2} \mathrm{SO}_{4}, \mathrm{~K}_{2} \mathrm{SO}_{4}$ and $\mathrm{HgO}$ to digest the sample. $\mathrm{NO}_{3}^{-}, \mathrm{NO}_{2}^{-}$and $\mathrm{NH}_{4}{ }^{+}$in the $\mathrm{K}_{2} \mathrm{SO}_{4}$ extracts were measured on a Skalar SANplus Segmented Flow autoanalyzer (Mulvaney, 1996).

\subsection{Microcosm preparation}

The soils were conditioned by sieving through a $5-\mathrm{mm}$ sieve, adjusting them to $40 \% \mathrm{WHC}$ by adding distilled water and maintaining them at $22 \pm 2^{\circ} \mathrm{C}$ for 7 days in drums. The microcosms were prepared in flasks containing $20 \mathrm{~g}$ of conditioned soil and $300 \mathrm{mg} \mathrm{L}^{-1}$ of added fluoranthene (99.9\% purity, Sigma-Aldrich, St. Louis, MO, USA). The flasks were placed in $945-\mathrm{mL}$ glass jars containing a vessel with $10 \mathrm{~mL}$ of distilled $\mathrm{H}_{2} \mathrm{O}$ and a vessel with $20 \mathrm{~mL}$ of $1 \mathrm{M} \mathrm{NaOH}$ to trap the evolved $\mathrm{CO}_{2}$. The jars were sealed and stored at 22 $\pm 2^{\circ} \mathrm{C}$. Microcosms without fluoranthene (containing only acetone, where the fluoranthene was dissolved) were included. To study the effect of fluoranthene adsorption in soil, microcosms were composed of OAS and CAS and sterilized by moist heat (thrice), followed by addition of $300 \mathrm{mg} \mathrm{L}^{-1}$ of fluoranthene (named as sOAS- and sCAS-microcosms). For the bioaugmentation test, the CAS-microcosm with the $300 \mathrm{mg} \mathrm{L}^{-1}$ of fluoranthene was inoculated once with $1.5 \mathrm{ml}$ of a consortium containing $1.5 \times 10^{8} \mathrm{UFCmL}^{-1}$ of fluoranthene-degrading bacteria. All of the microcosms were incubated for $0,3,7,14$ and 28 days. On the designated days, nine flasks were selected at random from each treatment and the soil was analyzed for fluoranthene, $\mathrm{CO}_{2}$ production, bacterial counts, and bacterial community monitoring. The remaining jars were opened and aired for 10 min to avoid anaerobiosis and then closed and incubated again. 


\subsection{Enumeration of soil bacteria}

Total heterotrophic bacteria and fluoranthenedegrading bacteria were determined by the viable count method using surface spreading techniques on nutrient agar and mineral salts medium with $100 \mathrm{mg} \mathrm{L}^{-1}$ of added fluoranthene, respectively. Soil suspensions were prepared by 10 -fold serial dilutions with $1 \mathrm{~g}$ of soil, and $0.1 \mathrm{~mL}$ of dilution was spread on plates in triplicate. The results were expressed as the number of colony-forming units per gram of soil (CFU g-1 ${ }^{-1}$ soil).

\subsection{Fluoranthene analysis}

The remaining fluoranthene in the soil microcosms was extracted by sonication and quantified by high-performance liquid chromatography (HPLC) as described in Fernández-Luqueño et al. (2008). Briefly, a 1.5-g sub-sample of soil was mixed with $3 \mathrm{~g}$ of anhydrous sodium sulfate and placed in a tube; immediately afterwards, $15 \mathrm{~mL}$ of acetone was added and the tube was mechanically shaken on a vortex for $15 \mathrm{~s}$. The tube was then placed in a sonicated bath at $35-40{ }^{\circ} \mathrm{C}$ for $40 \mathrm{~min}$. The extract was separated from soil by centrifugation at $3500 \mathrm{rpm}$ for $15 \mathrm{~min}$ at $20{ }^{\circ} \mathrm{C}$. This process was repeated three times to obtain the maximum fluoranthene recovery. The extracts were combined, evaporated and dissolved in $1 \mathrm{~mL}$ of methanol. A $2.0 \mu \mathrm{L}$ aliquot was analyzed for fluoranthene in a HPLC system with an ultraviolet detector (UV) using a Discovery C18 column (25 cm x $4.6 \mathrm{~mm}$, ID $5 \mu \mathrm{m})$. The mobile phase used was methanol-water

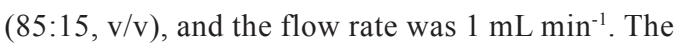
percentage recovery of fluoranthene was tested by adding $1.0 \mathrm{~g}$ of dry soil of each sample (CAS and
OAS) to tubes and spiking them with $200 \mathrm{mg}$ of fluoranthene. Fluoranthene in soil was then extracted as described above. Recovery of fluoranthene was $90 \%$. A fluoranthene standard was used to build a calibration curve before each analysis. All assays were performed individually nine times.

\subsection{DNA extraction and Denaturing Gradient Gel} Electrophoresis (DGGE) analysis

Total DNA was extracted directly from CAS and OAS by a series of washes with $0.15 \mathrm{M}$ sodium pyrophosphate and $0.15 \mathrm{M}$ phosphate buffer $(0.15$ $\mathrm{M} \mathrm{NaH}{ }_{2} \mathrm{PO}_{4}, \mathrm{pH}$ 8.0). The sediment was then resuspended in lysis solution I $(0.15 \mathrm{M} \mathrm{NaCl}, 0.1 \mathrm{M}$ EDTA, pH 8.0, $10 \mathrm{mg} \mathrm{mL}^{-1}$ lysozyme) and lysis solution II $(0.1 \mathrm{M} \mathrm{NaCl}, 0.5 \mathrm{M}$ Tris-HCl, $\mathrm{pH}$ 8.0, $12 \%$ sodium dodecyl sulfate). The sample was treated with two cycles of freezing at $-70^{\circ} \mathrm{C}$ for 20 min and thawing at $65{ }^{\circ} \mathrm{C}$ for $20 \mathrm{~min}$. Afterwards, the supernatant was recovered and $2.7 \mathrm{~mL}$ of $5 \mathrm{M}$ $\mathrm{NaCl}$ and $2.1 \mathrm{~mL}$ of Triton $\mathrm{X}-100$ in $0.7 \mathrm{M} \mathrm{NaCl}$ were added. The tube was shaken and incubated at $65{ }^{\circ} \mathrm{C}$ for $10 \mathrm{~min}$. Then, chloroform-isoamyl alcohol was added and the tube was mixed and centrifuged. The solution was transferred to a clean tube, polyethylene glycol was added, and the mixture was incubated at $4{ }^{\circ} \mathrm{C}$ overnight and centrifuged. The DNA pellet was resuspended in sterile deionized water, washed with $70 \%$ ethanol and dried at $65{ }^{\circ} \mathrm{C}$. The sediment was resuspended with $300 \mu \mathrm{L}$ of sterile deionized water. The bacterial community dynamics of the microcosms were evaluated by PCR-DGGE analysis of the V6-V8 regions of 16S rRNA gene using previously described oligonucleotides and conditions (Ortega-González et al., 2013). 
The central portion of strong DGGE bands were cut and cloned with a pCR 2.1-TOPO ${ }^{\circledR}$ cloning kit (Invitrogen, Carlsbad, CA, USA) according to the manual's instructions. Afterwards, they were sequenced with the ABI PRISM 310 Genetic Analyzer (Applied Biosystems, Foster City, Calif., USA). The sequences were tested for chimeras by using the Chimera-Check program of the Ribosomal Database Project (RDP) at the website http://rdp.cme. msu.edu/html/. The obtained partial 16S rRNA sequences were then submitted to a BLAST search to obtain the best matching sequences.

\subsection{Obtention of a fluoranthene-degrading bacterial consortium}

A composite sample of $1 \mathrm{~g}$ was inoculated in a flask containing $100 \mathrm{~mL}$ of minimal medium with the following composition per liter: $\mathrm{KH}_{2} \mathrm{PO}_{4}$ $(0.68 \mathrm{~g}), \mathrm{Na}_{2} \mathrm{HPO}_{4}(1.79 \mathrm{~g}), \mathrm{FeSO}_{4} \cdot 7 \mathrm{H}_{2} \mathrm{O}(0.4$ $\mathrm{mg}), \mathrm{MgSO}_{4} \cdot 7 \mathrm{H}_{2} \mathrm{O}(0.35 \mathrm{~g}), \mathrm{NH}_{4} \mathrm{NO}_{3}(1 \mathrm{~g}), \mathrm{CaCl}_{2}$ $(0.8 \mathrm{~g})$, and $0.1 \mathrm{~mL}$ of a solution of $100 \mathrm{mg} \mathrm{L}^{-1}$ of $\mathrm{MnSO} 4, \mathrm{ZnSO}_{4}, \mathrm{CuSO}_{4}, \mathrm{H}_{3} \mathrm{BO}_{4}$, and $\mathrm{CoCl}_{2}$, using $100 \mathrm{mg} \mathrm{L}^{-1}$ of fluoranthene (Sigma-Aldrich) as the sole carbon source. The flask was incubated at 30 ${ }^{\circ} \mathrm{C}$ and $120 \mathrm{rpm}$ until the culture reached an optical density at $600 \mathrm{~nm}$ ranging from 0.25 to 0.30 . Subsequently, $10 \mathrm{~mL}$ of the culture was transferred to $100 \mathrm{~mL}$ of fresh mineral medium, supplemented with $100 \mathrm{mg} \mathrm{L}^{-1}$ of fluoranthene and incubated under the conditions described above. This procedure was repeated five additional times to obtain a fluoranthene-degrading consortium named IPN-LO-02. To ensure the fluoranthene-degrading capacity of the consortium, preliminary assays in minimal medium supplemented with 100, 200, 300 or $400 \mathrm{mg} \mathrm{L}^{-1}$ of fluoranthene were performed. The percentage of residual fluoranthene and maximum growth velocity at 14 days were evaluated.

\subsection{Molecular identification of the bacterial consortium isolates}

To isolate and identify the members of the fluoranthene-degrading bacterial consortium IPN-LO-02, serial decimal dilutions to $10^{-6}$ were prepared from the last enrichment culture, and the bacteria were isolated by spreading $0.1 \mathrm{~mL}$ of the dilutions onto nutrient agar plates (BD, Mexico, DF, Mexico), with a single addition of $100 \mathrm{mg} \mathrm{L}^{-1}$ of fluoranthene. The culture media were incubated at $28{ }^{\circ} \mathrm{C}$ until the onset of microbial growth, which occurred one to two weeks later. The isolates were grouped according to their colonial and microscopic morphologies and were identified by their partial $16 \mathrm{~S}$ rRNA gene sequences (500 bp) in accordance with the conditions described previously in OrtegaGonzález et al. (2013). Their gene sequences were deposited in GenBank with accession numbers from KJ410678 to KJ410681.

\section{Results}

\subsection{Physicochemical assessment of OAS and CAS}

The physicochemical properties of the analyzed soils showed some differences. OAS had higher

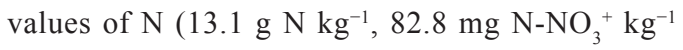
and $0.39 \mathrm{mg} \mathrm{N}-\mathrm{NO}_{2}{ }^{+} \mathrm{kg}^{-1}$ ), organic $\mathrm{C}$ (13.9 $\mathrm{g} \mathrm{C}^{-}$ $\left.\mathrm{kg}^{-1}\right)$ and sand $\left(300 \mathrm{~g} \mathrm{~kg} \mathrm{soil}^{-1}\right)$ than CAS, indicating a more fertile soil, although the texture of both soils was silt loam. CAS had higher values of $\mathrm{pH}$ (8.1), electrical conductivity $\left(0.6 \mathrm{dS} \mathrm{m}^{-1}\right)$, silt (737 $\left.\mathrm{g} \mathrm{kg} \mathrm{soil}{ }^{-1}\right)$ and clay $\left(207 \mathrm{~g} \mathrm{~kg} \mathrm{soil}^{-1}\right)$ than OAS (Table 1). Other characteristics, such as the cation exchange capacity, WHC and $\mathrm{P}-\mathrm{PO}_{4}{ }^{3-}$, showed no significant differences between the soils $(P>0.05)$ (Table 1). 
Table 1. Characteristics of organic agricultural soil (OAS) and conventional agricultural soil (CAS).

\begin{tabular}{|c|c|c|c|c|c|c|c|c|c|c|c|c|c|c|}
\hline Soil & $\mathrm{pH}$ & $\mathrm{CEC}^{1}$ & $\mathrm{EC}^{2}$ & $\mathrm{WHC}^{3}$ & Organic $\mathrm{C}$ & Total N & Silt & Clay & Sand & $\mathrm{P}-\mathrm{PO}_{4}{ }^{3-}$ & $\mathrm{N}-\mathrm{NO}_{3}{ }^{-}$ & $\mathrm{N}-\mathrm{NO}_{2}{ }^{-}$ & $\mathrm{N}-\mathrm{NH}_{4}{ }^{+}$ & Textural soil \\
\hline & & $\left(\mathrm{cmol}(+) \mathrm{kg}^{\mathrm{l}}\right)$ & $\left(\mathrm{dS} \mathrm{m} \mathrm{m}^{1}\right)$ & 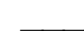 & -( & (g kg soil ${ }^{-1}$ & - & 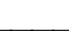 & - & 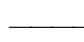 & $-(\mathrm{mg} \mathrm{kg} \mathrm{s}$ & $\left.\mathrm{il}^{-1}\right)$ & - & Classification \\
\hline OAS & $7.9 \mathrm{~b}$ & $12.0 \mathrm{a}$ & $0.4 \mathrm{~b}$ & $88.5 \mathrm{a}$ & $13.9 \mathrm{a}$ & $13.1 \mathrm{a}$ & $633 \mathrm{~b}$ & $63 \mathrm{a}$ & $300 \mathrm{a}$ & $18.7 \mathrm{a}$ & $82.8 \mathrm{a}$ & $0.39 \mathrm{a}$ & 0 & Silt loam \\
\hline CAS & $8.1 \mathrm{a}$ & $16.7 \mathrm{a}$ & $0.6 \mathrm{a}$ & $130.3 \mathrm{a}$ & $8.2 \mathrm{~b}$ & $6.8 \mathrm{~b}$ & $737 a$ & $207 \mathrm{~b}$ & $53 \mathrm{~b}$ & $15.5 \mathrm{a}$ & $45.73 \mathrm{~b}$ & $0.12 \mathrm{~b}$ & 0 & Silt loam \\
\hline
\end{tabular}

${ }^{1} \mathrm{CEC}$ : cation exchange capacity, ${ }^{2} \mathrm{EC}$ : electrical conductivity, ${ }^{3} \mathrm{WHC}$ : water holding capacity. A one-way ANOVA was performed using Tukey's test. Means $(\mathrm{n}=9)$ with the same letter do not differ significantly $(p>0.05)$.

\subsection{Effect of fluoranthene on the bacterial communities of $O A S$ and $C A S$}

To determine whether fluoranthene had an effect on the bacterial communities of OAS and CAS, an analysis of the PCR-DGGE profiles was performed in both soils. Fluoranthene did not alter the dynamics of the native microbiota of the microcosmsbecause a similar banding pattern was observed during the test days in the OAS-microcosm (Figure 1a) and CAS-microcosm (Figure 1b). Furthermore, a similar banding pattern was observed in the OAS and CAS, suggesting that the use of fertilizers and pesticides on the CAS had no effect on the native microbiota. Because PCR-DGGE analysis only detects the presence of genomic DNA and cannot assess the viability of bacteria, one viable bacteria count was performed to confirm that fluoranthene did not modify the native microbiota. The total heterotrophic bacteria counts at the initial stage of the degradation kinetics in the OAS- and CASmicrocosms without fluoranthene were $5.0 \pm 0.5$ x $10^{7}$ and $5.6 \pm 0.5 \times 10^{7}$ cell $\mathrm{g}^{-1}$ soil, respectively.
At the final stage of the degradation kinetics, no significant changes in the heterotrophic bacteria counts were observed in either microcosm. A similar result was found for the OAS- and CAS-microcosms with added fluoranthene, and no significant difference were observed compared with their respective counterparts without fluoranthene (Figure 2a). Regarding potential cultivable fluoranthenedegrading bacteria, a similar effect was observed in all microcosms studied, with an average count of $2.8 \pm 0.5 \times 10^{5}$ cell g $\mathrm{g}^{-1}$ soil (Figure $2 \mathrm{~b}$ )

Because fluoranthene had no effect on the bacterial community dynamic in the microcosms, the metabolic activity of soil microorganisms was measured by their respiratory activity $\left(\mathrm{CO}_{2}\right.$ production). The OAS- and CAS-microcosms with added fluoranthene showed a significant increment in $\mathrm{CO}_{2}$ production compared to the microcosms without fluoranthene $(P<0.05$, Figure $3 \mathrm{a})$.

The sOAS- and sCAS-microcosms (adsorption controls) did not exhibit respiratory activity (Figure 3a). The increased microbial respiration suggests improved metabolic activity without cellular division for fluoranthene removal. 


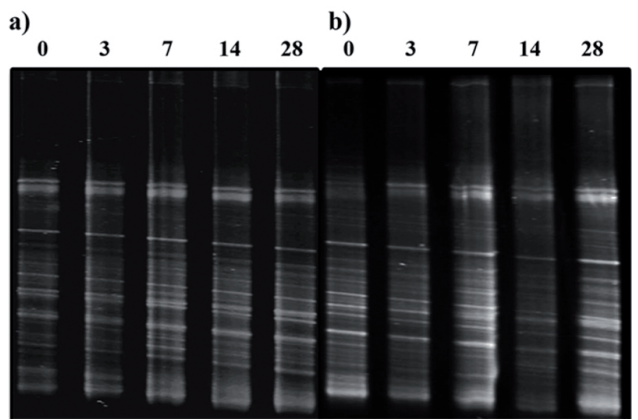

Figure 1. Effect of fluoranthene on the native microbiota of an agricultural soil. PCR-DGGE banding profiles of the 16S rRNA gene from agricultural soil microcosms with added fluoranthene were obtained. (a) Microcosm composed of OAS (organic agricultural soil); (b) microcosm composed of CAS (conventional agricultural soil). The numbers $0,3,7,14$, and 28 indicate the sampling days during the degradation kinetics.
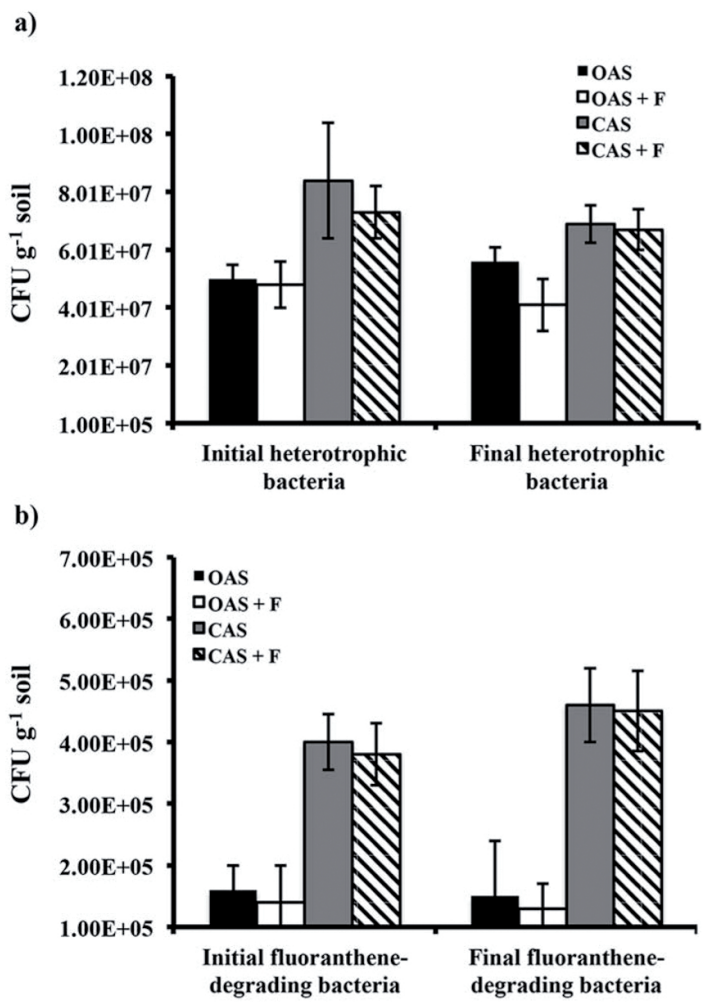

Figure 2. Enumeration of soil bacteria in the microcosms. Bacterial counts of (a) heterotrophic bacteria and (b) fluoranthene-degrading bacteria were performed at the initial and the final stages of the degradation kinetics (CFU g ${ }^{-1}$ soil). OAS (organic agricultural soil), OAS+F (organic agricultural soil with $300 \mathrm{mg} \mathrm{L}^{-1}$ of added fluoranthene), CAS (conventional agricultural soil), and CAS+F (conventional agricultural soil with $300 \mathrm{mg} \mathrm{L}^{-1}$ of added fluoranthene). The values shown are the average \pm the percentage of the standard error of three independent experiments. The "t-student" test was performed comparing the initial and final CFU of each microcosm. 


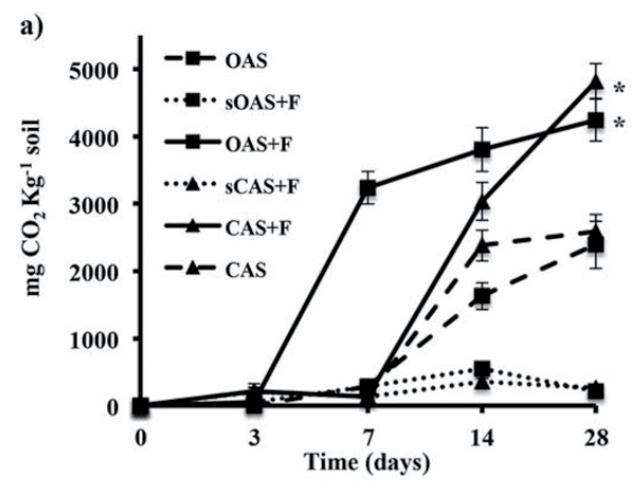

b)
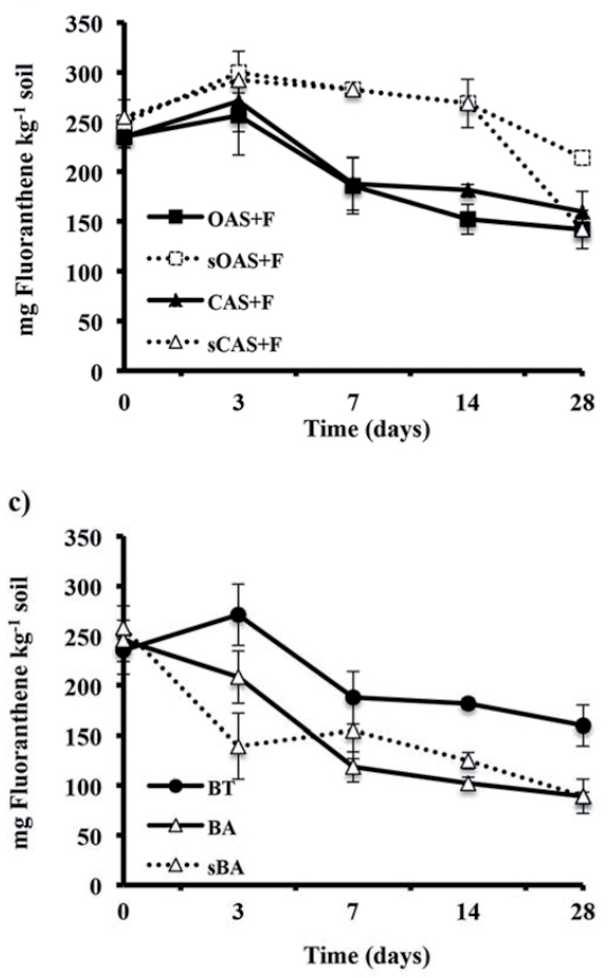

Figure 3. Removal of fluoranthene in microcosms made with agricultural soils. (a) Cumulative production of $\mathrm{CO}_{2}$ in $\mathrm{OAS}$ (organic agricultural soil), $\mathrm{OAS}+\mathrm{F}$ (organic agricultural soil with $300 \mathrm{mg} \mathrm{L}^{-1}$ of added fluoranthene), sOAS+F (sterile organic agricultural soil with $300 \mathrm{mg} \mathrm{L}^{-1}$ of added fluoranthene, as the inactivated biotic control), CAS (conventional agricultural soil), $\mathrm{CAS}+\mathrm{F}$ (conventional agricultural soil with $300 \mathrm{mg} \mathrm{L}^{-1}$ of added fluoranthene), and sCAS $+\mathrm{F}$ (sterile conventional agricultural soil with $300 \mathrm{mg} \mathrm{L}^{-1}$ of added fluoranthene, as the inactivated biotic control); (b) removal of fluoranthene in the OAS- and CAS-microcosms; (c) bioaugmentation (BA) and bioattenuation (BT) effects on the CAS-microcosm with $300 \mathrm{mg} \mathrm{L}^{-1}$ of added fluoranthene. sBA (sterile CAS and the consortium. Bars represent the standard error, and each point on the graph is the mean of nine independent assays. * Significant difference $(\mathrm{P}<0.05)$ between $\mathrm{OAS}+\mathrm{F}$ and $\mathrm{OAS}$ or $\mathrm{SOAS}+\mathrm{F}$ and between $\mathrm{CAS}+\mathrm{F}$ and CAS or sCAS+F. One-way ANOVA was performed using Tukey's test. 


\subsection{Removal of fluoranthene in OAS- and CAS- microcosms}

To determine whether there was a relationship between microbial respiration and fluoranthene removal in the microcosms tested, the residual fluoranthene in soil was quantified during dynamic removal. The OAS- and CAS-microcosms exhibited similar behaviors during fluoranthene removal $(p>0.05)$. Fluoranthene removal began on day 3, and on day 28 , the highest removal percentage of $43 \%$ was obtained (Figure $3 b$ ). The effect of fluoranthene adsorption in both soils (using the sOAS- and sCAS-microcosms with added fluoranthene as adsorption controls) showed an insignificant removal of fluoranthene until day 14; after that point, the sCAS-microcosm reached a similar removal as that of the CAS-microcosm $(p>0.05)$. During days 7 and 14, there was a significant difference between the OAS- and CAS-microcosms compared to their corresponding adsorption controls $(p<0.05$; Figure $3 \mathrm{~b})$.

\subsection{Characterization of the fluoranthene-degrading bacterial consortium}

The bacterial consortium used in the bioaugmentation assay was characterized. The maximum growth velocities for the consortium were 0.14 , $0.29,0.35$, and $0.27 \mathrm{~d}^{-1}$ for concentrations of 100 , 200, 300 and $400 \mathrm{mg} \mathrm{L}^{-1}$ of fluoranthene, respectively, while their corresponding initial consumption velocities were $1.1,3.5,4.01$ and $3.3 \mathrm{mg} \mathrm{L}^{-1}$ $\mathrm{d}^{-1}$. Because the bacterial consortium LO-IPN-02 performed best at $300 \mathrm{mg} \mathrm{L}^{-1}$ of fluoranthene, this concentration was used in the microcosm assays. Molecular identification of the cultivable members of the bacterial consortium was performed by analysis of their 16S rRNA gene sequences, and
Bacillus sp. Flu1, Bacillus pumilus Flu2, Bacillus pumilus Flu3, and Pseudomonas nitroreducens Flu4 were identified.

\subsection{Removal of fluoranthene in the CAS-microcosm by bioaugmentation}

To determine whether fluoranthene removal could be improved by bioaugmentation, the bacterial consortium LO-IPN-02 was incorporated in the CAS-microcosm. The bioaugmented CASmicrocosm (BA) reached a higher percentage of fluoranthene removal than the non-bioaugmented CAS-microcosm (bioattenuated or BT) on days 14 $(59.4 \%)$ and $28(64.4 \%)$ of the incubation period $(p<0.05$; Figure $3 c)$. To assess the involvement of the consortium in fluoranthene removal, a microcosm composed of sterile CAS and the consortium (sBA-microcosm) was included. The results of the sBA-microcosm and BA-microcosm were similar (Figure $3 \mathrm{c}$ ), indicating that the members of the consortium LO-IPN-02 participated in the removal of fluoranthene. To demonstrate the adaptation of the bacterial consortium LO-IPN-02 in the CAS-microcosm, a PCR-DGGE was performed. The BA-microcosm and BT-microcosm did not exhibit significant changes in the DGGE banding profile during the incubation period of 28 days (Figure 4). Afterwards, four representative bands (a-d) of the DGGE (Figure 4) were excised from the gel, sequenced, and submitted to a BLAST search to obtain the closest related sequences in the GenBank database. The sequences were identical to deposited sequences: band a was related to Bacillus sp. (AB425351), band b to Pseudomonas sp. (PSU37339), band c to Bacillus safensis (KM888116), and band d to Pseudomonas sp. (PSU37339) (Figure 4). 


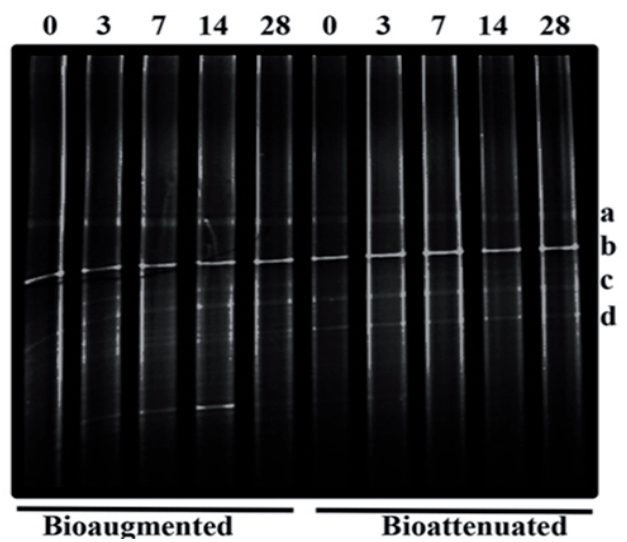

Figure 4. Evaluation of the microbiota under bioaugmentation and bioattenuation techniques in OAS-microcosms. PCR-DGGE banding profiles of the $16 \mathrm{~S}$ rRNA gene from OAS microcosms with added fluoranthene were obtained. The numbers $0,3,7,14$, and 28 indicate the sampling days during the degradation kinetics. Letters from a to $\mathrm{d}$ are the excised and sequenced bands from the gel.

\section{Discussion}

Few studies have been performed on fluoranthene degradation at the microcosm level (Song et al. 2016; Zeng et al., 2010). In these works, the involvement of the indigenous bacterial community in fluoranthene removal, soil physicochemical properties and land agricultural practices were not explored simultaneously. The stability of indigenous bacterial communities of soil is important for the successful removal of contaminants. Furthermore, land agricultural practices (the use/management of fertilizers and pesticides) and the physicochemical properties of a soil can influence the permanence or removal of contaminants. Under these considerations, fluoranthene removal (used as a compound model of PAHs) by the indigenous bacterial community of an OAS and CAS was explored in the present study, taking into account the physicochemical properties of the soils. Regarding the latter, OAS had higher values of $\mathrm{N}$ and organic $\mathrm{C}$ than $\mathrm{CAS}$, indicating a more fertile soil. A high amount of organic $\mathrm{C}$ can reduce the use of HMW-PAHs as a source of carbon for the native soil microorganisms. CAS had more clay than OAS, which could have an effect on the adsorption of PAHs (Zielińska and Oleszczuk, 2016; Wu et al., 2011). It is important to determine the physicochemical parameters of soil to enhance the removal of a contaminant. Thus, Azubuike et al., (2016) suggested that the physicochemical parameters of a soil should be known beforehand to choose the best bioremediation strategy. The results of the present study suggest that the high content of organic $\mathrm{C}$ in OAS and the higher content of clay in CAS negatively affected the biodegradation of fluoranthene.

The involvement of the indigenous bacterial community in fluoranthene degradation was analyzed. At the molecular level, PCR-DGGE analysis showed a similar banding profile in all microcosms; at the microbiological culture level, no significant changes in the heterotrophic bacteria count and cultivable fluoranthenedegrading bacteria were observed in microcosms with and without fluoranthene. However, a high metabolic activity (determined indirectly by the production of $\mathrm{CO}_{2}$ ) was observed in the presence of fluoranthene. The heterotrophic bacteria count reported in this study was in agreement with those of other studies (Johnsen 
and Karlson, 2005; Simarro et al., 2013) Similar to the report by Simarro et al. (2013) the heterotrophic bacteria counts were two orders of magnitude higher than contaminant-degrading bacteria. It has been reported that the soil microbial population changes with the addition of a contaminant (Yan et al., 2016) and that a specific microorganism selection takes place (Barbato et al., 2016). Furthermore, the ring structure of PAHs influences this microbial selection (Muckian et al., 2007). Our results suggest that the bacterial communities of both soils were tolerant and capable of surviving the toxicity level produced by fluoranthene because no alteration of the soil microorganisms was observed. The toxicity of fluoranthene could also be mitigated by the physicochemical properties of the soils, where fluoranthene adsorption by silt, clay or sand was able to reduce its negative effect on microorganisms (Ghosal et al., 2016), or by native soil microorganisms with the ability to remove it.

Data on the fluoranthene degradation kinetics suggest the involvement of indigenous bacterial communities in OAS and CAS; however, the abiotic controls (sCAS and sOAS) showed decreased fluoranthene by the end of the incubation time. The phenomenon of fluoranthene adsorption in the sCAS-microcosm could have occurred due to the high silt and clay contents. This result shows that the indigenous soil microbiota is initially involved in fluoranthene removal and that the effect of soil adsorption occurs afterwards. Our results are supported by Yang et al. (2010), who indicated that sequestration is the major mechanism for the accumulation of PAHs in soils. Additionally, the soils used in this study had high concentrations of $\mathrm{C}$ and $\mathrm{N}$; therefore, soil microorganisms did not need fluoranthene as a source of $\mathrm{C}$, which could have occurred in the OAS-microcosm.

Regarding bioaugmentation, the results of the present study suggest that CAS easily incorporated exogenous microorganisms and consequently enhanced fluoranthene removal. Previous studies reported that the addition of microorganisms had negligible effects on the removal of PAHs at the field or microcosm level (Simon et al., 2004; Viñas et al., 2005). In our study, bioaugmentation was achieved, although the added fluoranthene-degrading consortium apparently did not modify the population structure of the indigenous bacterial community of CAS since the DGGE banding profile was similar between the BA-microcosm and BT-microcosm. This result suggests that the native microbiota was stable and possibly prevented the establishment of foreign microorganisms in the environment. However, this result is controversial because other works demonstrated that the addition of a microbial consortium in polluted soils changed the microbial diversity, without radical removal of pollutants by indigenous microorganisms (Wang et al., 2014; Viñas et al., 2005), or that the addition of a microbial consortium had a positive effect on PAHs-removal (Sharma et al., 2016). Another possibility is that the members of the bacterial consortium LO-IPN-02 were already present in the CAS environment. The nucleotide sequences of the four representative PCR-DGGE bands corresponded to Bacillus sp. (AB425351), Pseudomonas sp. (PSU37339), Bacillus safensis (KM888116), and Pseudomonas sp. (PSU37339). Bacteria detected by PCR-DGGE were similar to the bacterial genera present in the consortium used for bioaugmentation (Bacillus sp. Flu1, Bacillus pumilus Flu2, Bacillus pumilus Flu3, and Pseudomonas nitroreducens Flu4), which may explain the similar DGGE banding profile in both microcosms. These results suggest that it is important to know the bacterial population structure associated with the soil to ensure the success of a bioaugmentation assay because the added microorganisms must be compatible or related to the indigenous microbiota. Crop management and addition of fertilizers (Channabasava et al., 2015; Chrysargyris and Tzortzakis, 
the indigenous bacterial community. However, in the present study, there were no significant differences between OAS and CAS, suggesting that the fertilizers and pesticides added to CAS did not affect the indigenous bacterial community nor the degradation of fluoranthene. Soil characteristics can also contribute to the removal of PAHs. The distribution of PAHs in soil mainly depends on the hydrophobicity of the compounds and their affinity towards microcompartments of the soil aggregates, reducing the bioavailability to the microorganisms and thus slowing their removal (Rein et al., 2016). Some authors suggest that the removal of contaminants becomes difficult with aging as the rate of desorption of PAHs in an aging polluted soil decreases, leading to the difficulty in determining their residual persistence and concentration, even in the presence of native microorganism with the capacity to remove PAHs (Abdel-Shafy and Mansour, 2016).

\section{Conclusion}

The present study showed that during fluoranthene removal at the microcosm level, it is important to consider the physicochemical characteristics of the soils, land agricultural practices (OAS o CAS) and native microbiota associated with the soils. Indigenous microorganisms were very stable and significantly counteracted the presence of fluoranthene through biological removal; subsequently, fluoranthene was adsorbed to the soil. Furthermore, the native microbiota was friendly to the foreign microorganisms used in the bioaugmentation assay.

\section{Acknowledgments}

This research was supported by the Instituto Politécnico Nacional (IPN) México grant SIP20161060. $\mathrm{OJHH}$ and LREV received grant-aided support from the Consejo Nacional de Ciencia y Tecnología (CONACyT). MSVM, JCCD, and JJR would like to thank the COFAA and EDI, Instituto Politécnico Nacional fellowships, and the support of the Sistema Nacional de Investigadores, CONACyT.

\section{References}

Abdel-Shafy H. I., Mansour M. S. M. 2016. A review on polycyclic aromatic hydrocarbons: source, environmental impact, effect on human health and remediation. Egypt. J. Petrol. 25, 107-123.

Azubuike C.C., Chikere, C.B., Okpokwasili, G.C. 2016. Bioremediation techniques-classification based on site of application: principles, advantages, limitations and prospects. World J. Microbiol. Biotechnol. 32, 180.

Barbato, M., Mapelli, F., Magagnini, M., Chouaia, B., Armeni, M., Marasco, R., Crotti, E., Daffonchio, D., Borin, S. 2016. Hydrocarbon pollutants shape bacterial community assembly of harbor sediments. Mar. Pollut. Bull. 104, 211-220.

Channabasava, A., Lakshman, H.C., Jorquera, M.A. 2015. Effect of fungicides on association of arbuscular mycorrhiza fungus Rhizophagus fasciculatus and growth of Proso millet (Panicum miliaceum L.). J. Soil Sci. Plant Nutr. 15, 35-45.

Chrysargyris A., Tzortzakis, N.2015. Municipal solid wastes and mineral fertilizer as an eggplant transplant medium. J. Soil Sci. Plant Nutr. 15, 11-23.

Crisafi, F., Genovese, M., Smedile, F., Russo, D., Catalfamo, M., Yakimov, M., Giuliano L., Denaro, R.2016. Bioremediation technologies for polluted seawater sampled after an oil-spill in Taranto Gulf (Italy): A comparison of biostimulation, bioaugmentation and use of a washing agent in microcosm studies. Mar Pollut. Bull. 106, 119-26. 
Fernández-Luqueño, F., Marsch, R., Espinosa-Victoria, D., Thalasso, F., Hidalgo-Lara, M.E., Munive, A., Luna-Guido, M.L., Dendooven, L. 2008. Remediation of PAHs in a saline-alkaline soil amended with wastewater sludge and the effect on dynamics of C and N. Sci. Total Environ. 402, 18-28.

Ghosal, D., Ghosh, S., Dutta, T.K., Ahn, Y. 2016. Current state of knowledge in microbial degradation of polycyclic aromatic hydrocarbons (PAHs): A Review. Front. Microbiol. 7, 1369.

Haritash, A.K., Kaushik, C.P. 2009. Biodegradation aspects of polycyclic aromatic hydrocarbons (PAHs): a review. J. Hazard. Mater. 169, 1-15.

Jin, J., Yao, J., Liu, W., Zhang, Q., Liu, J. 2016. Fluoranthene degradation and binding mechanism study based on the active-site structure of ringhydroxylating dioxygenase in Microbacterium paraoxydans JPM1. Environ. Sci. Pollut. Res. Int. 24, 363-371

Johnsen, A.R., Karlson, U. 2005. PAH degradation capacity of soil microbial communities-does it depend on PAH exposure?. Microb. Ecol. 50, 488-495.

Long Y.H, Li R.Y., Wu X.M. 2014. Degradation of Smetolachlor in soil as affected by environmental factors. J. Soil Sci. Plant Nutr. 14, 189-198.

Muckian, L., Grant, R., Doyle, E., Clipson, N. 2007. Bacterial community structure in soils contaminated by polycyclic aromatic hydrocarbons. Chemosphere. 68, 1535-1541.

Mulvaney, R.L. 1996. Nitrogen-inorganic forms. In: D.L. Sparks (ed). Methods of Soil Analysis, Part 3: Chemical Methods, 3rd Edition. Soil Science Society of America, Inc., Madison, WI, USA, pp: 1123-1184.

Ortega-González, D.K., Zaragoza, D., Aguirre-Garrido, J., Ramírez-Saad, H., Hernández-Rodríguez, C., Jan-Roblero, J. 2013. Degradation of benzene, toluene, and xylene isomers by a bacterial consor- tium obtained from rhizosphere soil of Cyperus sp. grown in a petroleum-contaminated area. Folia Microbiol. (Praha). 58, 569-577.

Rein, A., Adam, I. K., Miltner, A., Brumme, K., Kastner, M., Trapp, S. 2016. Impact of bacterial activity on turnover of insoluble hydrophobic substrates (phenanthrene and pyrene)-Model simulations for prediction of bioremediation success. J. Hazard. Mater. 306, 105-114.

Rhoades, J.D., Mantghi, N.A., Shause, P.J., Alves, W. 1989. Estimating soil salinity from saturated soilpaste electrical conductivity. Soil Sci. Soc. Am. J. 53, 428-433.

Sharma, A., Singh, S.B., Sharma, R., Chaudhary, P., Pandey, A.K., Ansari, R., Vasudevan, V., Arora, A., Singh, S., Saha, S., Nain, L. 2016. Enhanced biodegradation of PAHs by microbial consortium with different amendment and their fate in in-situ condition. J. Environ. Manage. 181, 728-736.

Simarro, R., González, N., Bautista, L.F., Molina, M.C. 2013. Assessment of the efficiency of in situ bioremediation techniques in a creosote polluted soil: change in bacterial community. J. Hazard Mater. 262, 158-167.

Simon, M.A., Bonner, J.S., Page, C.A., Townsend, R.T., Mueller, D.C., Fuller, C.B., Autenrieth, R.L. 2004. Evaluation of two commercial bioaugmentation products for enhanced removal of petroleum from a wetland. Ecol. Eng. 22, 263-277.

Song, M., Jiang, L., Zhang, D., Luo, C., Wang, Y., Yu, Z., Yin, H., Zhang, G. 2016. Bacteria capable of degrading anthracene, phenanthrene, and fluoranthene as revealed by DNA based stableisotope probing in a forest soil. J. Hazard Mater. 308, 50-57.

Sprocati, A.R., Alisi, C., Tasso, F., Marconi, P., Sciullo, A., Pinto, V., Chiavarini, S., Ubaldi, C., Cremisini, C. 2012. Effectiveness of a microbial formula, as a bioaugmentation agent, tailored for 
Viñas, M., Sabaté, J., Espuny, M.J., Solanas, A.M. 2005. Bacterial community dynamics and polycyclic aromatic hydrocarbon degradation during bioremediation of heavily creosote contaminated soil. Appl. Environ. Microbiol. 71,7008-7018.

Wang, T., Sun, H., Mao, H., Zhang, Y., Wang, C., Zhang, Z., Wang, B., Sun, L. 2014. The immobilization of heavy metals in soil by bioaugmentation of a UV-mutant Bacillus subtilis 38 assisted by NovoGro biostimulation and changes of soil microbial community. J. Hazard Mater. 278, 483-90.

Wu, X.M., Li, M., Long, Y.H., Liu, R.X., Yu, Y.L., Fang, H., Li, S.N. 2011. Effects of adsorption on degradation and bioavailability of metolachlor in soil. J. Soil Sci. Plant Nutr. 11, 83-97.

Yan, L., Sinkko, H., Penttinen, P., Lindström, K. 2016. Characterization of successional changes in bacterial community composition during bioremediation of used motor oil-contaminated soil in a boreal climate. Sci. Total Environ. 542, 817825.
Yang, Y., Tao, S., Zhang, N., Zhang, D.Y., Li, X.Q. 2010. The effect of soil organic matter on fate of polycyclic aromatic hydrocarbons in soil: a microcosm study. Environ. Pollut. 158, 1768-1774.

Zeng, J., Lin, X., Zhang, J., Li, X. 2010. Isolation of polycyclic aromatic hydrocarbons (PAHs)-degrading Mycobacterium spp. and the degradation in soil. J. Hazard Mater. 183, 718-723.

Zielińska, A., Oleszczuk, P. 2016. Attenuation of phenanthrene and pyrene adsorption by sewage sludge-derived biochar in biochar-amended soils. Environ. Sci. Pollut. Res. Int. 23, 21822-21832. 